\title{
"My Daughter is not like That": A Qualitative Study of Parental Perception on Child Sexual Abuse Risk
}

\author{
Eelmaa Simone $e^{\bowtie}$ \\ University of Tartu, Tartu, Estonia \\ 凶simone.eelmaa@ut.ee
}

Introduction. Parental prevention efforts on child sexual abuse (CSA) are paramount for children to have better protection. However, parental awareness and beliefs are essential constituents influencing parental prevention efforts. Previous studies have revealed that parents tend to judge child sexual abuse as a low risk to their children, which in turn impacts CSA prevention activities. The aim of this study was to explore parental beliefs on the risk of CSA, specifically victim- and perpetrator-specific risk of child sexual abuse to their children, as well as parents' approaches to protecting their children.

Methodology and sources. Data were collected from 22 parents during focus group interviews $(n=6)$ combined with activity-oriented questions.

Results and discussion. Based on data, four perpetrator and two victim-specific risk profiles were created. When parents find similarities between their children and perceived victims or perpetrators, it triggers the defensive othering effect, which acts as a subconscious protection mechanism, yet often creates inaccurate risk assessment and false confidence. The findings also tender that most parents do not teach their children the necessary skills related to CSA since they determine the risk to be low.

Conclusion. This study adds to our understanding of CSA-related risk perception and prevention approaches, offering a conceptual addition to the defensive attribution theory. Further investigation is needed on the impacts of the cognitive processes and psychological protection mechanisms in relation to CSA risk assessment. The data from this study will be useful in developing CSA prevention programs and materials.

Key words: child sexual abuse, defensive othering, focus groups, othering, parent-led CSA education, risk perception.

For citation: Ealmaa S. "My Daughter is not like That": A Qualitative Study of Parental Perception on Child Sexual Abuse Risk. DISCOURSE. 2021, vol. 7, no. 2, pp. 56-80. DOI: 10.32603/2412-8562-2021-7-2-56-80.

Source of financing: the work was supported by a grant from Estonian Research Council (project No. PRG700 "Vulnerability in childhood and vulnerable subjectivity: interdisciplinary comparative perspective").

Conflict of interest. No conflicts of interest related to this publication were reported.

Received 16.01.2021; adopted after review 11.03.2021; published online 23.04.2021

(c) Eelmaa S., 2021

Контент доступен по лицензии Creative Commons Attribution 4.0 License.

This work is licensed under a Creative Commons Attribution 4.0 License. 


\title{
«Моя дочь не такая»: качественное исследование родительского восприятия риска сексуального насилия над детьми
}

\author{
С. Ээльма \\ Тартуский университет, Тарту, Эстония \\ 凶simone.eelmaa@ut.ee
}

\begin{abstract}
Введение. Родительские меры по предотвращению сексуального насилия над детьми чрезвычайно важны для обеспечения более эффективной защиты детей. Однако основными составляющими превентивных мер со стороны родителей являются информированность и убеждения родителей. Предыдущие исследования показали, что родители склонны считать риск сексуального насилия в отношении своих детей низким, что, в свою очередь, влияет на меры по предотвращению сексуального насилия над детьми. Цель настоящего исследования состоит в изучении родительских убеждений по поводу риска сексуального насилия над детьми, и в особенности связанного с преступником и жертвой риска сексуального насилия в отношении их детей, а также подходов родителей к обеспечению безопасности детей.
\end{abstract}

Методология и ресурсы. Данные были получены от 22 родителей в ходе интервью фокус-групп (n=6) с применением практических заданий.

Результаты и обсуждение. На основании полученных данных были созданы четыре профиля риска, связанного с преступником, и два профиля риска, связанного с жертвой. Когда родители обнаруживают у своих детей общие характеристики с преступниками или жертвами, это провоцирует эффект защитного отчуждения, который играет роль подсознательного защитного механизма, но часто приводит к неправильной оценке риска и ложной уверенности. Полученные наблюдения также указывают на то, что родители не обучают своих детей навыкам, связанным с риском сексуального насилия, потому что определяют этот риск как низкий.

Заключение. Настоящее исследование углубляет наше понимание восприятия риска в связи с сексуальным насилием над детьми и подхода к его предотвращению, предоставляя понятийное дополнение к теории защитной атрибуции. Требуется дальнейшее исследование влияния когнитивных процессов и механизмов психологической защиты на оценку риска сексуального насилия над детьми. Данные настоящего исследования будут использованы в материалах и программах по предотвращению сексуального насилия над детьми.

Ключевые слова: сексуальное насилие над детьми, защитное отчуждение, фокус-группы, отчуждение, восприятие риска.

Для цитирования: Ээльма С. «Моя дочь не такая»: качественное исследование родительского восприятия риска сексуального насилия над детьми // ДИСКУРС. 2021. Т. 7, № 2. C. 56-80. DOI: $10.32603 / 2412-8562-2021-7-2-56-80$.

Финансирование: работа выполнена при финансовой поддержке гранта Эстонского научного агентства (проект №PRG700 «Уязвимость в детстве и уязвимая субъективность: интердисциплинарная сравнительная перспектива»).

Конфликт интересов. О конфликте интересов, связанном с данной публикацией, не сообщалось.

Поступила 16.01.2021; принята после рецензирования 11.03.2021; опубликована онлайн 23.04.2021

Introduction. Protecting children from sexual abuse (CSA) is the collective responsibility of parents, schools, and communities. Primary prevention serves best since it helps all children 
gain the necessary skills and knowledge for better protection and does not stigmatize those at risk [1]. Although parents tend to have a fairly decent understanding of CSA, they do not provide children with accurate messages [2]. However, there are only a few qualitative inquiries on parental risk perception and approaches to prevention. To help fill this gap, parents' beliefs about victim- and perpetrator-specific risk to CSA and parental approaches to protecting their children are explored in this paper.

Previous studies reveal that parents tend to judge sexual abuse as a low risk to their children [3-6] and, due to such beliefs, do not engage in CSA prevention activities or discussions with their children. The topic's uncomfortable nature adds to the matter: parents feel they do not have the knowledge or vocabulary to discuss the issue [6]. Besides the reluctance to discuss the matter with their children due to low-risk assessment [4], insufficient knowledge or lack of confidence [7], some parents fear discussing CSA would cause children to know too much about sex [8]. Furthermore, Collins [5] found that some parents feel that if they are good enough parents and can keep their children safe, they do not need to teach their children about safety or other prevention matters. Parents may also feel sexual abuse is not a severe direct threat to their children [9], but rather a problem of generalized "others". The lack of general awareness of CSA and considering the risk of CSA to be low are common barriers to parental discussions of CSA with their children [10,11]. Briggs [12] found three out of four parents do not discuss CSA or sexual boundaries with their children at all, while another study demonstrated 40 percent of parents not having those discussions with their children [3]. A more recent study revealed that around 55 percent of parents had these discussions [13].

Another issue is the still prevailing misconceptions regarding child sexual abuse and online grooming. For example, one common parental suggestion for CSA prevention is wearing appropriate clothing [14], which reflects a belief that victimization is under the control of the victim. Another is the still-common practice of teaching children about the "stranger danger" [3, $8,10,14-16]$, and deliberately or not, parents tend to focus on the idea that children ought not to engage in online activities with strangers. A strong focus is on conveying the possible consequence of kidnapping as a result of sharing information or establishing relationships with strangers [17]. However, these approaches reflect a common misconception that sexual predators are mainly strangers who prey on children, when, in fact, friends and other acquaintances make up a substantial portion of perpetrators [18]. A report from 2007 showed that in 30 to $50 \%$ of sexual abuse cases, the perpetrator was an adolescent [19]. In general, these numbers match with online forms of sexual offending against children [20].

Disclosing sexual abuse is a complicated and dialogical process influenced by individual, contextual, familial, and cultural hallmarks [21]. A 2009 study showed most children do not disclose abuse immediately, almost $60 \%$ delay disclosure for more than five years, and around $20 \%$ had never told anyone [22]. With bothersome online experiences, around one-third of children reported discussing their concerns with a parent [23]. Nonetheless, as turning to a parent was found to be approximately five times more likely than seeking help from a teacher, parental mediation may have a crucial role in children disclosing their concerns or turning to a parent for information on sensitive issues [23]. Children who have the necessary knowledge are more likely to disclose sexual abuse [24]; hence teaching children the necessary skills about the risk of CSA both online and offline may be of vital importance. 
Risk perception itself is a crucial factor in influencing behavior. Moreover, given that parents who perceive the risk of CSA as higher are more likely to discuss CSA with their children [13], parental risk perception warrants further inquiry. Collins [4] also studied parents' perceptions of the risk of CSA and found a discrepancy between their risk perception of other children compared to their own. However, that study was conducted over 25 years ago and may not provide an adequate understanding of the current situation, particularly as technology has profoundly evolved over time. In the current paper, parental beliefs on the risk of CSA and their respective roles in protecting their children are explored. For this purpose, answers to the following research questions are sought:

1. Whom do parents see as potential risks and whom they see potentially at risk of CSA?

2. How do parents view their children in relation to these risk profiles?

3. How do parents view keeping their children safe from sexual abuse?

Methodology and sources. The epistemological foundation of this study was social constructionism [25, pp. 42-44]. Qualitative methods enabled to explore and uncover how parents understand and make sense of sexual abuse and related risks and their underlying attitudes and perceptions about the issue. The study was designed and piloted from spring 2019 until the beginning of empirical data collection in late 2019. Though a real-time face-to-face interview mode was initially planned, a dyadic interview setting for collecting data on this topic appeared impractical. Firstly, discussion in a group setting facilitates the natural flow of a conversation, where the synergy between participants serves to elicit responses without much interference from the researcher. The dynamic of reciprocally stimulating conversation is, in most cases, absent in individual interviews where participant merely gives direct answers to specific questions. The group dynamic has the potential to produce more diverse topics and themes, as the interactional setting may feel more comfortable and encouraging for participants [26-28], as well as less constraining. Secondly, the interplay between participants enables insight into the language and vocabulary [26] commonly used to describe beliefs about sexual abuse victims and perpetrators. As language is a form of social practice and is determined by social structures [29, pp. 22-27], the interactional approach helps to understand better the metalevel of these discussions, the possible roots of their views, and the use of language that is comfortable and intelligible for participants. Also, the process of data collection in focus groups provides an additional facet to the data - interactions between participants [28]. Ergo, focus group interviews combined with activity-oriented questions [30] were utilized for collecting data.

Participants and recruitment. 22 participants, aged 26-to-47, were purposively recruited using online possibilities. A maximum variation sampling was used to reflect a range of demographics (such as gender, age, ethnicity, family demographics). An invitation to participate was forwarded via primary and secondary schools' mailing lists and a neurodivergence themed Facebook group. Schools were selected by the largest public schools by student population from three different regions across the country. The Facebook group was chosen to include the voice of parents of neurodiverse children $(n=2)$. Parents who did not have school-aged children, good command of Estonian, or had only adult children were excluded from the study. Participants were parents of 1 to 4 children (55\% of children were daughters). All participants had at least one school-aged child; around half of the participants were also parents of toddlers or preschoolers. Though all fathers interested in participating in the study were included in the 
sample $(n=6)$, mothers represented a majority $(n=16)$. The sample included 17 Estonians and five Russians (one male, four female). Good command of the Estonian language was determined during recruitment efforts. Though the designated sample included 29 eligible participants, 7 people withdrew or did not attend for other reasons. Financial incentive was not provided for participation.

Procedure. Data was gathered using focus group interviews combined with activity-oriented questions. Stratified randomization was used to allocate participants into three groups based on their geographical location. Next, computer-generated randomization was done on each group to randomly allocate participants into focus groups. The only exception was parents from the same household who insisted on participating together and were added to the focus group from their region with the least participants. Three groups included mothers and fathers and three solely mothers. Focus groups took place across Estonia, in urban and suburban areas in three different regions. Interviews were audio-recorded, conducted in Estonian, and the length of each varied from 1 to 2 hours.

Six focus group interviews were conducted; each consisted of three to four participants. The small group size was chosen purposively for 2 main reasons: to ensure all participants could actively take part in conversations and to provide a more intimate and secure atmosphere for discussions. More sizable groups would have made these goals far difficult to achieve. As the groups were small, getting to know other participants and remembering their names was rather effortless and, in turn, made the overall ambiance relaxed even before the interview formally started. The suitable location was always chosen by bearing in mind the convenience for participants and the overall ambiance of regular everyday conversational situations. All the focus groups were held in informal settings (i. e., in a living-room area, café, or a patio in the backyard).

The sensitive nature of the study was explained to parents during recruitment efforts to make sure potential participants could make an informed decision to participate in the study. Upon meeting, participants were introduced to each other and accosted with refreshments of their preference and an opening conversation about participating in research. Besides starting a conversation between participants, I was able to get some insight into their thoughts, worries, and expectations regarding their participation in the study. At the beginning of interviews, research aims, ethical and legal considerations of participation, and what would be done with the results were explained; we also agreed upon some ground rules for discussions. I explained that there are no right or wrong answers, that everyone's views are important, and that one can always refrain from participating or take back their overall consent without the need to explain anything [31]. We agreed to respect others' views and refrain from judgments on others' accounts. I assured participants that in case of any distress or discomfort, they can always refrain from participating, take a break, or decide not to participate in the study. I also explained my role as a moderator but not a participant in discussions. After, every participant's informed consent and permission to use an audio-recorder was elicited. For background information, parents were asked to state their age, the number of children they have, and the age and gender of their children. Safeguarding and supporting participants' psychological and emotional wellbeing was central throughout the research process [31]. While facilitating focus groups, due attention was given to the general atmosphere of discussions, participants' interactions with each other, and 
any visible distress. Interactions between participants were mostly limited to encouraging sharing, even in accounts of subversive views.

Measures. The study was designed in 3 stages, each focusing on a separate topic: general knowledge of CSA, knowledge and perception of CSA risk, and prevention of CSA. Each stage started with an assignment prescribed to be completed either as a group or individually and was followed by a group discussion apart from the 2nd stage, which had 2 assignments. Around 15 minutes were given for each assignment and the following discussion in the group (accounting for an estimation of 60 minutes for four assignments). This activity-oriented approach was chosen due to the sensitive nature of the study as discussion concurrent or following practical activities may help to reduce stress and discomfort with the topic, allow participants more time to reflect and organize their ideas [30], and engage all participants simultaneously in the deliberation of their answers. Before each assignment, it was reminded that there is no consensus requirement, and all views are valuable.

For the 1st assignment, participants were given a pen and paper and asked to do the following: "Please map sexual risks ${ }^{1}$ together as a group. Also, provide a meaning to each risk" (translated from Estonian). The exact format was chosen by participants; mostly concept maps and lists were used. In the 2nd stage, participants were given two assignments. Firstly, to individually draw or write down whom they considered as a person who would sexually harm children, and then to present and discuss their views in the group. And then, to work together as a group and create a profile of children who, according to their views, are at risk. ${ }^{3}$ The last assignment was a combination of case vignettes and role enactments (role-play) on issues related to CSA prevention, disclosure, and help-seeking. Assignments were conducted without moderator's interference. After finishing each assignment, follow-up questions were asked by the moderator to elaborate or specify things that seemed unclear. ${ }^{4}$ After finishing discussions, I asked how participants were feeling about discussing such topics. Parents were keen to ask about possible approaches to issues or available resources on the topic; the most common concern was how to start these conversations with their children. I answered their questions and agreed to provide more detailed information and resources later via email. I encouraged them to write any follow-up questions or concerns and assured them that results and publications related to this study would be shared with them when finished [31].

${ }^{1}$ The term sexual risks was not further defined or explained, it was up to participants to decide what and how they define as sexual risks. The assignment also did not include a reference to children because the pilot test showed that framing the question (in different ways) that includes the phrase children leads participants or creates a bias (e. g., sexual risks to children, sexual risks children may encounter, sexual risks that threaten children, sexual risks children may be exposed to etc.). Also, the pilot further showed that the use of the term would need either an explanation that children in this study means anyone under the age of 18, or should be accompanied with a term referencing to adolescents (though this term is not necessarily limited to people below 18). Furthermore, as articipants were informed during recruitment and at the beginning of the study that children are the focus of this study, the assignment description was clear even without any reference to them. For those reasons any reference to children was excluded from the assignment description.

2 The phrase "risks" (in Estonian) was used since the pilot test showed that (Estonian) phrases exploitation, abuse or crime create a strong disposition towards (physically) violent acts. The phrase "risks" was found to be the most suitable for the study.

${ }^{3}$ As parents already mapped out and discussed different acts they consider as sexual risks, the assignment did not need to specify further.

${ }^{4}$ Some examples of follow-up questions: ,you mentioned earlier that they must be sick, can you tell me what do you mean by that?", ,you mentioned a dysfunctional family, can you explain that a little? “, ,,can someone please explain me again what role does bad parenting have? ", „, you mentioned that they should learn these things at school, can you clarify what was meant by that?", ,, what has been the hardest in such discussions with your children?, ,, what kind of information would be helpful for preventional matters?". 
During focus groups, I made reflective notes about relevant observations from interactions, emerging themes, and patterns in discussions, issues, or statements that needed follow-up questions and practical methodological considerations. The data from these memos were concurrently analyzed to improve the data collection process and to understand emerging themes and patterns in focus groups to demarcate reaching the data saturation point and cease the data collection.

Data Analyses. For the transcription of data, all participants were given a pseudonym, and all references to personal data such as names or places were redacted to ensure the protection of participants' interests. Data was analyzed with a six-step thematic analysis: (1) transcribing and familiarizing myself with the data; (2) initial coding; (3) theme search; (4) systematization of themes into a thematic map; (5) defining and naming the themes; followed by (6) analysis and writing the article [32]. The inductive data-driven approach was used to answer research questions.

Findings were categorized into four key themes: (a) parental perceptions on victims of CSA; (b) parental perceptions on perpetrators of CSA; (c) parental views on their children in relation to these risk profiles; and (d) parental beliefs about the role of parents in CSA risk and approaches to protect their children. Though other themes also emerged, ${ }^{5}$ these do not fit the focus of this article. Constructions of parental perceptions related to victims and perpetrators of CSA are labeled throughout this study as "risk profiles," though let me emphasize that the profiles presented in the findings section are not provided to represent an accurate or objective depiction of the risk of CSA, but as constructions of subjective perceptions and beliefs held by parents participated in the study.

Profiles were named by the author using words most used by parents in the context of each specific profile. Though some parents immediatelly expressed that there are different types of perpetrators, most parents created one profile that included some or most of the characteristics across profiles (presented in the Results section) presented initially as one general risk profile. However, it became evident during group discussions that these are not general characteristics, but mostly, certain characteristics apply only to certain profiles. Following the data, 4 different perpetrator profiles were constructed. Similar patterns were seen with discussing victim-related risk. Parents created 1 profile which included many different characteristics, yet as the reasoning (related to risk) and parental attitudes towards some characteristics differed, it was pertinent to categorize these characteristics accordingly. This is how 2 types of victim "profiles" were constructed. The risk arising from parents is also presented in the Results section, though creating such a profile was not part of any assignment during focus groups, nor did parents create it purposively. The data for parental risk profiles impacting CSA risk was gathered from consistent references to it during discussions.

Results. The findings are presented as 4 key themes.

\section{Theme 1: Parental perceptions of victims of child sexual abuse.}

Parents' attitudes on the CSA risk perception related to victims were roughly divided into 2 . Parents held that some children are unfortunate and victimized because adults fail them, and then

\footnotetext{
5 Examples of some additional themes in the data - 1. parental views on the harmfulness of encountering sexual risks; 2. what is considered a sexual risk; 3 . online vs offline sexual risks; 4. responsibility to protect; 5 . criteria for deciding an act to be criminal; 6 . sources of information.
} 
some are exploited due to personal decisions or factors that increase their vulnerability. The outline of whom do parents consider to be at a higher risk of CSA victimization is presented in fig. 1 below. For clarity, risk profiles are named Type One and Type Two.

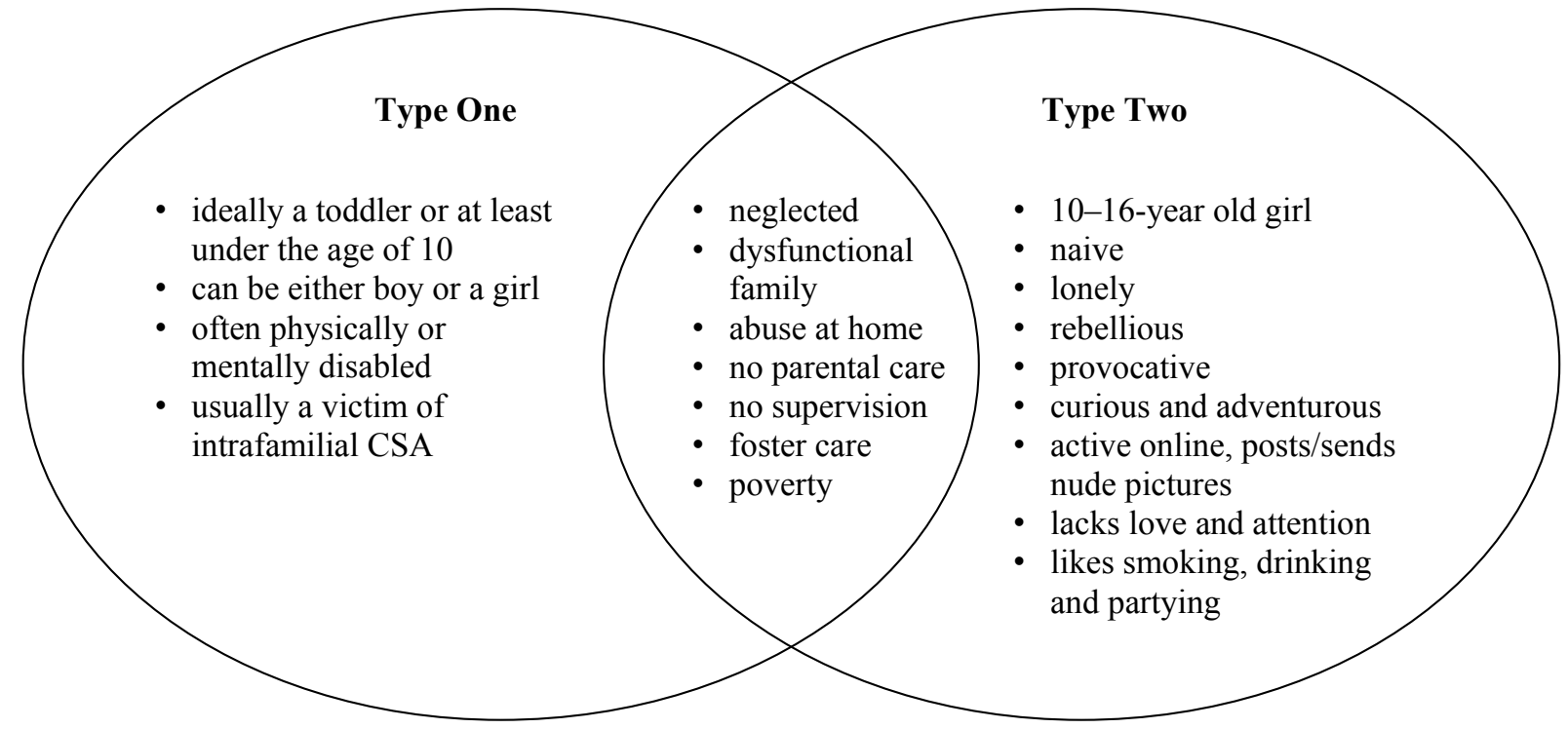

Fig. 1. A construction of victim risk profiles perceived by parents

1.1. Characteristics of the Type One victim profile. According to parents, Type One victims are toddlers or young children, who could be either boys or girls and in many cases are disabled. Either way, parents agreed that due to their age or disability, children were unable to fight back or protect themselves from abuse. Parents also assumed online sexual risks seldom threaten Type One victims since they said to be small children who are not as active or reachable online. Though some parents suggested that the online component of abuse could be present if the perpetrator, for instance, shares child sexual abuse material (CSAM) of the child, yet this was seen more as an exception to the general pattern.

Parents mostly described Type One by relying on uniform characteristics that cannot be changed or controlled by the victim, such as age or gender. The Type One victims were spoken about empathetically, and there was no apparent victim-blaming present in discussions. Parents believe that these children face a number of adverse health outcomes due to ongoing abuse. In one focus-group, parents went further to discuss that abusers specifically target children below the age of comprehension or ability to fight back as a strategy to ensure both ongoing and easy access to the victim, and to mitigate the chances of getting caught. Parents agreed that murdering victims to protect themselves from getting caught is unlikely since the abuse is rarely remembered, believed, and young children are unable to seek help. Parents said that the most likely scenario is that the perpetrator seeks a new victim who meets the criteria. Another explanation was that when victims of intrafamilial CSA become older and understand what was done to them, they may feel intense shame and decide to keep it a secret, but not all parents agreed to this being feasible. The general tendency was associating Type One victims with intrafamilial CSA.

1.2. Characteristics of the Type Two victim profile. Type Two victims are girls between the ages of 10-16-years. Parents constructed this risk profile with characteristics associated with psyche, attitude, behavior, and appearance. Type Two victims were systematically blamed and 
sometimes even shamed by parents. It was nearly a consensus that some young people are sexually abused because they seek adventures and thrill. A more substantial consensus among parents was that in most cases where CSA is occurring online or starts with online communication, the child is more engaged and may even be seeking attention - even sexual attention - so is more vulnerable to CSA. Some parents elaborated that in many cases, adults take advantage of these girls because such girls are naive and lonely. One persistent inclination was asserting that smart children would not go along with such things (e. g., sexting, live sexual interactions). It was also claimed that adults' actions do not actually harm these girls since they know what they are getting into, and they choose themselves to proceed with these "relations". It was said to be common knowledge that if young people post sexualized pictures, dress and act provocatively, and go to parties with adults, they are seeking sexual encounters. While trying to determine whether the actions discussed were crimes or immoral acts, parents used the legal age of consent as a compass.

I16: Well, it is not rape just because it is a minor, I think the age [of consent] is 14 or so. But yes, I have heard stories. /.../ Thank God my cousin waited with the police thing, they would have just ruined some young man's life because of a story.

I17: That is what I was trying to say. These girls can say anything...

I18: I think it is still wrong to have sex with minors.

I16: Well, being wrong is not a crime.

According to parents, Type Two victims are both capable of understanding and physically resisting the abuse. Type Two victims were objectified and portrayed not as children but as sexual beings who ought to understand the possible consequences of their actions. The responsibility for "being victimized" was again and again projected to Type Two victims. Almost every participant in the study held Type Two as at least partially responsible. Though victimblaming was sometimes rather subtle (e. g., saying that these girls should be more careful with partying in the wrong crowd,) at other times, the blaming was very straightforward and even lessened the blame of the perpetrator (e. g., it is not the guy's fault that the girl was so drunk and acted provocatively). In sum, parents believed that these things do not happen randomly but mainly to those who "choose" to put themselves at risk. Though some parents did not agree with the notion that Type Two victims are necessarily looking for sexual encounters, since instead, they might be seeking attention, nice things, or money, it was said that these girls should be diligent because their behavior could lead to exploitation.

1.3. The comparative aspects between these risk profiles. The use of language already indicated an apparent disparity between attitudes towards victims. A recurrent practice was that parents while discussing Type Two profile, used the words "relations," "relationships," or "having sex" instead of the words "crime," "violence," "abuse," or "exploitation." Type Two victims were given an agenda of being able to decide or control the risk of victimization at least to a certain extent, and that being so, the abuse was repeatedly rephrased to something less serious. Such practice was not present while discussing Type One victims where phrases "crime," "violence," "abuse," or "exploitation" were used. Another disparity was regarding the expressions used while referencing to children at higher risk of CSA. For Type One, expressions such as a "child" or "victim" were most often used, while for Type Two, "girls", "youth" and 
"young women" were preferred. Language use and characteristics related to age, psyche, attitude, behavior, and appearance were mostly differing between profiles, but there was a common denominator for both types: the parenting factor. This included socio-economic variables and family-specific elements. It was expressed that these things happen to more unfortunate children in our society. The parenting factor is further discussed in Section 4.1.

\section{Theme 2: parental perceptions of perpetrators of CSA.}

Table below is a schematized depiction of four different perpetrator types. The specifics of each risk profile are discussed below, and the last section of this theme addresses the gender implications on threat assessment.

An outline of CSA perpetrator risk profiles with dominant characteristics expressed by parents

\begin{tabular}{|c|c|}
\hline The pervert & The pedophile \\
\hline $\begin{array}{l}\text { - a foreign man (i. e., of a different race or } \\
\text { ethnicity); } \\
\text { - 30+ of age; } \\
\text { - lonely; } \\
\text { - intrusive; } \\
\text { - overweight; } \\
\text { - addicted to pornography; } \\
\text { - using obscene vocabulary }\end{array}$ & $\begin{array}{l}\text { - friendly; } \\
\text { - middle-aged; } \\
\text { - often a gay male; } \\
\text { - addicted to pornography; } \\
\text { - has a childhood trauma; } \\
\text { - living with his mother or married and } \\
\text { stepfathering the child he is abusing; } \\
\text { - particular or notable appearance (e. g., } \\
\text { mustache and glasses) }\end{array}$ \\
\hline $\begin{array}{r}\text { The exhibitionist } \\
\end{array}$ & $\begin{array}{c}\text { The spoiled rich kid } \\
\end{array}$ \\
\hline $\begin{array}{l}\text { - male; } \\
\text { - in his 50s or older; } \\
\text { - usually an alcoholic; } \\
\text { - intellectually disabled; } \\
\text { - unable to understand the consequences of } \\
\text { his actions; } \\
\text { - unclean and unkempt appearance }\end{array}$ & $\begin{array}{l}\text { - male; } \\
\text { - young adult; } \\
\text { - arrogant; } \\
\text { - irresponsible; } \\
\text { - overindulged; } \\
\text { - good-looking; } \\
\text { - usually from a wealthy family }\end{array}$ \\
\hline
\end{tabular}

2.1. The pervert is a foreign man seeking contact via online possibilities. According to parents, foreign means a different race or ethnicity. The pervert is usually at least 30 years of age, lonely, intrusive, habitually using profanity, and believed to be addicted to pornography. Some parents mentioned that perverts are often overweight. The pervert was seen as the most dangerous of the four profiles. Firstly, parents held that foreign perverts are remarkably prevalent online. Here, parents did not rely on current information (e. g., news coverage, criminal cases, statistics) but on their anecdotal experiences from many years ago. The "foreign pervert" was someone most of the parents in their twenties and thirties had come across when they were teenagers; more specifically, parents referred to their experiences with people from Turkic ethnic groups in "MSN messenger". Secondly, since parents also tie the pervert profile with kidnapping and human trafficking, they associate the profile not only with fears related to CSA but with fears of never seeing their child again. The current political situation ${ }^{6}$ in Estonia also seemed to affect parental viewpoints. This was evidenced by some parents demonizing foreign men who, as they expressed, "come to Estonia to rape our women and girls", using racial slurs when talking about the pervert profile, and by claiming that perverts come from countries where rape culture is acceptable.

6 Among other things, the Conservative People's Party of Estonia (Estonian: Eesti Konservatiivne Rahvaerakond, EKRE) is considered a far-right and Eurosceptic party, which also opposes immigration and LGBT rights. The general public of the country has seen a great deal of party's racial, antisemitic, homophobic and islamophobic rhetorics, including associating refugees with sexual violence. In 2019, after a rather successful Parliamentary elections for the conservative party, these topics were also more present in public discussions. 
Parents think online perverts are rarely a threat to Type One since the latter is not as active online nor sufficiently fluent in English to be groomed. Thus, the highest threat is to Type Two victims. Parents believe that perverts offer compliments, attention, and money to get naive girls to meet with them or to engage in sexual activities online. However, parents did not see foreign perverts being much of a threat to their child: parents explained that their children are reasonable enough not to fall for it and would tell their parents if anything like this ever happened to them.

2.2. The pedophile is a middle-aged (40-60 years old) man, often claimed to be gay. According to parents, he most likely lives with his mother or is married and a stepfather to the child he is abusing. Parents think the pedophile was probably traumatized during childhood: either sexually abused, tortured, or otherwise maltreated. The pedophile is manipulative, yet he may seem friendly and knows how to communicate with children. People around him think he is a good person, which is why it is often difficult to believe the child over this type of offender. Parents believe he is also a porn addict. Some parents think they could recognize the pedophile.

I10: I don't know. If I try to picture a pedophile, I see a weirdo with a mustache and glasses.

I11: (laughing) ... precisely what I was thinking. And a cap.

I12: But I wouldn't let someone like that anywhere near my kid.

Parents believe the Internet is a means to find children or to distribute CSAM. Pedophiles seek vulnerable children who would not be believed or who cannot report or fight back (e. g., disabled children). Pedophiles often work with children (e. g., a teacher, a coach, or a cleric) or seek access through volunteering jobs (e. g., as a volunteer camp instructor). In general, parents name pedophile as a moderate-to-high risk to children and young people because (according to parents) pedophiles know how to prey on vulnerable children, often do this inside the family, leave a good impression of themselves to others, and ensure that children do not disclose or (if they do) are not believed. Parents also pointed out that abuse often goes on for many years before moving on to a new victim. Nevertheless, parents do not fear pedophiles as a moderate or high risk for their children because parents explained that pedophiles seek specific children, i. e., vulnerable children from certain families; and their children do not fit the potential victim profile. Adding to that assessment may be the reason parents categorized the "pedophile" threat as something more common elsewhere (e. g., in the US) than in Estonia. Explanations were strongly related to media coverage and representation of the profile in TV shows and juxtaposed with saying such horrible things rarely happen here. Also, some parents believed pedophiles somehow look odd or distinguishable, i. e., if you see them, you know not to trust them with your children.

2.3. The exhibitionist is an old man (in his 50s or older) and a drunkard who lives in a village or a small town. It was said that the exhibitionist most commonly has mental retardation, which, according to parents, means he cannot understand what he does is wrong or criminal. The exhibitionist was described to be slim, balding, dirty, toothless, and generally obscene. The exhibitionist was also called a "dirty old man". However, as parents explained, these people are mentally ill and often drunk, but are rarely a threat. The exhibitionist is believed not to pose an online threat to children at all. Some parents believed Estonians rarely sexually abuse children, akin to parent $\mathrm{I} 21$ below:

I19: Like Estonians, clearly do such things also... 
I21: I didn't mean to say they don't. I agree, they do. But in most cases, it's just some village drunkard. Somehow, I feel people from certain countries are more prone to attack sexually, groom kids and so on. I think we are raised better here.

As with the pervert profile, parents applied their memories to construct this profile, believing such people merely flash their private parts to girls and maybe touch themselves but rarely attack anyone. However, most parents put forward that the exhibitionist was more common during the 1990s (since personal experiences were restricted to that decade), and according to parents, nowadays we have better support for people with mental health issues and more technological advancements that help to provide a safer environment (e.g., security cameras in public places). As participants' children either live in the city or do not go out at night, they were not considered as a threat to their children.

2.4. The spoiled rich kid is a young (up until the age of 25) good-looking male, likable, (over)confident, and knows how to talk to girls. Parents believe "the rich kid" has been spoiled by his parents, and as a result, does not take no for an answer. Parents explained that the rich kid does not necessarily have bad intentions and is usually associated with Type Two victims who seek adventures and may meet men online or at a party. The rich kid either uses the girl or, after a girl flirts with him, believes the sexual activity is his due. This parallels the rhetoric applied to victims who use alcohol: victims are blamed, and potential perpetrators justified. Most parents determined this profile to be a moderate risk to children and young people in general and a low risk to their children. Besides that, some parents explained that the rich kid is a direct result of bad parenting; hence, by setting reasonable boundaries and punishments, such behavior patterns were said to be preventable.

2.5. Female perpetrators were not included in risk profiles; women were mentioned in relation to the "teacher-student" type of sexual abuse. However, "teacher-student" discourse was not considered to be either sexual violence or harmful, but instead, framed as a common fantasy for teenage boys:

I3: I don't think women do such things. At least I haven't heard about it...

I2: I just read about some teachers in the US.

I3: Oh, yes. Actually, I have read about those. Pretty frequently lately. But let's be honest, these are not rape cases. Yes, I think it is immoral to have sex with a student who is like 10 or 20 years younger than you, but these boys are not raped. For them, it is probably a fantasy coming true... (laughing).

I2: Exactly! Some women just like younger men. It is just the age difference, but I think it is unfair to make it a crime like it is in the US. And in these stories, they are not even that old. In the one I just read, the teacher was like 27 or so... But she looked younger, like 20.

As illustrated, most parents believe women do not sexually abuse children and that sexual offending, in general, is a deviancy related to men. Even when discussing the possibility of female sexual offending, the language evidenced it was not considered equally serious as with male offenders. The latter was considered a crime, but the former was expressed either as "relationships" or somewhat immoral acts; also, victims were phrased as young men.

\section{Theme 3: parental views on their own children in relation to these risk profiles.}

During discussions, comparisons or related references in relation to both victim and perpetrator risk profiles compared to participants' own children were made. 
3.1. Parental views on their children in relation to victim profiles evidenced that most often, parents tend to construct their children as different from potential victims, yet in general, there were three different approaches persisting. In case of similarities with Type Two profile and own children, which was present in approximately half of cases, parents were creating distance between their children and risk profiles by othering. Sometimes it was explicitly stated that their child is not like that, for example, as in the excerpt below:

I6: They even talk provocatively, not to mention the clothing...

I7: Thank God, my daughter is so reasonable and even shy; she would never wear such clothing. She has strong principles when it comes to these things, we've talked about it.

Such explanations were mainly used by parents whose children were in the Type Two age and gender cohort. The most common way for parents to construct this otherness was to explain that their child is a Good Child who is doing well in school and is not partying or seeking adventures. The Good Child idea was illustrated by discussions about different accomplishments children had (e. g., representing the school in math contest or winning trophies in athletic events). The Good Child was constructed as the opposite of the Type Two victim construct. Some parents also expressed that their children are reasonable enough to understand the consequences of their actions, that according to parents, meant the understanding that one could be raped at parties. According to parents, their children also behave reasonably on the Internet and do not talk to strangers. When participants referred to their children during discussions, almost all were considered as so-called "good children" who would not "put themselves at risk".

In contrast, parents with younger children, who fit Type One by age and gender, did not engage as actively in trying to construct this otherness or even stating differences between their child and the profile. Nevertheless, they did create otherness by focusing on parenting and environmentrelated factors, e. g., expressing that their children are still so young that they spend considerable time with parents, and wherefore are safe from sexual abuse. In general, this was enough for parents to deem the risk to be low. Yet, there was a notable exception to this tendency: a mother of three explained that her youngest $(8$ y. o.) daughter is intellectually disabled and needs constant adult supervision and care. As this was the only case in this study where a child had at least three similar characteristics with Type One profile (age, gender, disability), the mother admitted the risk to be higher: "she is unable to make reasonable decisions herself and cannot tell if someone is hurting her". Following, the mother promptly moderated the CSA risk by supposing that there are no matching family or environment-related risk factors. Furthermore, she submitted that she is more concerned about general risks to her daughter's safety but not as much about the risk of CSA, especially since her child is exclusively under the care of trusted people.

The third tendency was when parents were satisfied by the fact that their children were factually different from perceived victims by uniform characters (such as age and gender) and deemed the risk to be low without expressly stating differences or engaging in distancing activities. For instance, during discussions of own children and victim profiles, parents of teenage boys more often merely stated something akin that they are parents of teenage boys and therefore did not even consider or address the risk of CSA. These results propose that parents of teenage boys are most confident of their children not being at risk.

3.2. Parental views on their children in relation to perpetrator profiles suggested that most risk profiles were automatically exempt from deliberation, parents were referencing to the 68 
"spoiled rich kid" profile but not to other profiles. When parents were asked whether they have discussed topics of sexual risks with their children, an interesting phenomenon became evident in how fathers understood the question. Though the question was intended to investigate whether parents discuss risks with their children, fathers of sons reflexively answered as if they were concerned about their sons as potential perpetrators, not victims. Here are two answers (from different focus groups) from fathers with teenage sons:

I17: There has been no need to talk about such things. The boy knows where the line is drawn, what he can or cannot do. He's a good boy, always been protecting girls and been polite to them, I see no need to frighten him with these conversations.

19: Maybe just how to make it clear to him. That it is a crime, and you might think you are joking around or something, but if you send someone's naked pictures, you are committing a crime, and it could harm the girl. Though he is so reasonable, and I don't think he would do something like that...

Significantly, mothers never considered their children as potential perpetrators in this way, only fathers of sons did. None of the fathers had any previous experience relating this topic with their child; thus, they did not speak from experience but were communicating their beliefs and interpretations. It also seemed that the gender and age of participants' children influence parents' views, especially regarding "the spoiled rich kid" profile. One example of this paradox is offered below. Please observe how the mother of three kids below the age of ten (I18) approaches the topic compared to a father of a teenage son (I17).

I18: My friend told me about a lawyer's son who had sex with an unconscious girl - too much alcohol. So, I consider this rape. You cannot have sex with someone unconscious... And, of course, his dad saved him and made the whole thing go away.

I17: But were you there?

I18: No, but...

I17: Then, you cannot judge the situation. Honestly, I've seen more girls dressing and acting provocatively, drinking, and having sex with random guys at parties than I've heard about them getting raped. /.../

I16: My thoughts exactly. Like if you flirt with the guy and get so wasted that you cannot control yourself, it doesn't seem much like you care about your health or reputation. Or not wanting to have sex with someone. And if both are drunk and reckless, I think both are to blame but still, how is it that one part later has to take full responsibility for the other one's reckless drinking, moreover, get charged. /.../

I17: I don't know. My son can understand what's right and wrong and how to treat girls. Somehow it is this particular type of boys who gets into such troubles.

The mother (I18) did not try to construct "otherness" here; she also blames victims less compared to other participants in this discussion. With both fathers (I16 \& I17), one can see how they portrayed the actions of girls as deviant and provocative, and the actions of boys (who were considered potential perpetrators in that context) as not planning to rape anyone but merely "somehow getting in such troubles." As participant I17 has a teenage son, he also tried to clearly distinguish his son from this profile. Thus, regardless that fathers justify perpetrators' actions, they also try to distance their children from the risk of doing such things by othering. 
Theme 4: Parental beliefs about their role in CSA risk and approaches to protect their children.

4.1. Parental beliefs about their role in CSA risk clearly demonstrated the significance of parenting in their conceptualization of the risk. As mentioned in Section 3.1, the common denominator for children at risk to be victims of CSA was family-related factors. Here, parents once again constructed the perceived "otherness" mentioned above while discussing contrasting characteristics and behaviors believed to be associated with "good" and "bad parents." A "good parent" is the one who cares about their child's whereabouts and activities both online and offline, who controls online activities, who listens to their children, and is there for them in case of need. The "good parent" is not an addict or an alcoholic, is able to provide for their children financially, is not violent or otherwise dangerous, and knows how to raise "good" children.

As parents explained, these things happen when children are "misbehaving" themselves or when adults fail them. The latter was expressed through a link between bad parenting and increased risk of CSA. Parents also expressed the understanding that if they are Good Parents, abuse cannot happen to their child. One view was that some children are at risk due to their parents' ignorance, alcoholism, addiction, poverty, or other similar issues; another, that Type Two children have also had a challenging home environment, bad relations with their parents, or simply the "wrong upbringing." Examples of the wrong upbringing included, if a young mother lacks the necessary parenting skills and therefore is incapable of raising a child with the right values, or if the child is continuously exposed to bad role-modeling (e. g., a promiscuous mother). Note the gender implication: no participant mentioned the negative impacts of promiscuous fathers. Bad relations with parents were illustrated as a child who is not listened to or protected, and therefore, unable to turn to parents with their concerns. Some parents specifically mentioned that they believed themselves to be good enough parents to protect their children. Another common belief was that they have such good relations with their children and that if anything ever should happen, their children would come and tell them immediately.

I1: I am not afraid of that. I think I have such a strong bond with my kids that if some pedophile should start to harass them, I know they would come to me.

A general observation throughout the study is that parents are typically talking about themselves: sometimes directly, yet also indirectly, through contrasts between themselves and their family members to perceived victims or perpetrators of CSA.

4.2. Parental approaches to protect their children from CSA were also discussed during focus groups. Boys were seen as less at risk, specifically by fathers. Parents, in general, have not discussed these risks with boys since they are either not considered to be at risk or to be too young for such conversations. Boys (over the age of 12) were seen as strong and smart enough to handle stressful situations themselves. Though fathers were more likely to consider their sons as possible perpetrators than victims, they still saw no reason to scare or bother their sons with such topics, believing their boys to be well-raised and (therefore) to know how to treat girls both onand offline. When, in the minority of cases, parents have discussed CSA and prevention with their children, the focus was solely on male perpetrators. Most parents focused discussions on online perverts, as they were seen as the most dangerous of the perpetrator profiles. With online perverts, the main prevention message was to avoid strangers, as a rule, foreign men, online. To 
avoid pedophiles, parents used a similar language: do not go with or engage in conversations with a stranger. These messages were usually directed at daughters. All in all, "stranger danger" both in online settings and in the physical world is the most common thing parents teach their children. Parents do not teach their children about possible risks from peers or partners.

For parents, a high CSA threat is related to bad parenting, misbehavior, and attentionseeking girls, as well as certain perpetrator types. As the first 2 categories were deemed by parents to be low risk to their children, only such perpetrators whom they view to be dangerous are discussed at all. Even so, parents do not teach children skills or knowledge on situational risks (e. g., sending nude pictures). Behaviors deemed to be dangerous (i. e., sending nude pictures, talking to strangers) are either accompanied by threats of punishment; or not discussed at all. Many parents, particularly mothers, said they had discussions with their daughters about the appropriateness of specific clothing or make-up, e.g., that certain clothes are either too provocative or otherwise inappropriate. These conversations were not linked explicitly to CSA prevention.

Most prevention activities parents use are not explicitly related to CSA prevention. Though during discussions, it became evident that parents still use other methods they consider to lower risks of CSA for their children. The first is related to situational risk reduction. Here, parents explained that they do not leave children with people they do not trust, that their children never have to be or travel alone (e. g., walking home in the dark), or that they generally know where and with whom their child spends time. Parents explained that such practices are not explicitly related to protecting children from CSA but from other possible threats (e. g., getting hit by a car or getting lost). In their view, however, these factors also reduce the risks of CSA. Secondly, as parents believe that good parenting is key, this is where parents put most of their efforts. This includes having a good and trusting relationship with their children: listening to them, caring about them, and keeping up with their lives. Thirdly, parents believe that children have acquired good digital skills from school and from everyday use of the Internet in relation to recognizing and reducing online sexual risks - better, indeed, than their parents. And lastly, parents believe that restrictions on internet use are essential in decreasing the risk of CSA. Although again, restrictions were not explicitly linked to CSA (e. g., most associate internet restrictions with good grades and good behavior), parents believed that children who have easier and less restricted internet access are in greater danger than those with such restrictions.

Based on parents' accounts, the general focus of prevention is not related to CSA; in fact, parents tend to rather avoid discussing CSA specifically, preferring to focus on good parent-child relations, setting reasonable boundaries and restrictions, and being involved in children's lives.

Discussion. This study explored parental beliefs about child sexual abuse risk and recurring parental approaches to protecting their children from CSA. Parents believe that younger children with specific vulnerabilities (such as disability, foster care, poverty, neglect) are at higher risk of sexual abuse, mainly for being failed by adults who ought to protect them. However, with children over the age of 10 , the general tendency was relating victimization risk to children's behavior, character, and personality traits. Perceived victims were constantly derogated and portrayed as deviant, particularly those who were more different from participants' children. This confirms the effect of defensive attributions theory, which purports that people blame victims (and justify perpetrators) based on perceived similarity with the subject [33]. According to 
parents, victims of sexual abuse who are over the age of ten are often victimized due to their risk behavior and attention-seeking. Younger or otherwise more vulnerable children were approached with empathy and benevolence.

One factor influencing parental understanding and acknowledgment of the crime (of rape) may be the age of consent. Sociocultural environments largely determine the definition of rape [34], and as the age of consent in Estonia is 14: parents do not consider sexual intercourse with a minor rape per se but rather somewhat immoral. The use of language was a strong warrant for the differences in attitudes parents held towards victims. With Type One profile, children were considered victims of terrible crimes, yet with Type Two profile, abuse and violence were often reduced to "sexual relations gone wrong" or "immoral acts". Such normalizing of sexual violence or minimizing its impact is, unfortunately, a widespread practice in the wider victimblaming discourse [35, pp. 2-3]. In Estonia, most victims of (registered) sex crimes are minors with the average age of the victim being 12 [36]; thereby, such attitudes are highly concerning and may act as barriers to disclosure and help-seeking. All in all, the findings reveal that parental understanding of CSA victimization is strongly affected by gender stereotypes, sexual scripts, rape myths, and general misconceptions on CSA [35].

It is worth noting that parents continually contrasted conversation topics with their lives. The discussions indicated that when parents consider the risk of CSA to their child, the risk is largely determined based on perceived similarities with Type Two risk profile, yet mainly concerning fixed characteristics such as age and gender. Accordingly, it was more common for parents whose children were below the age of 10 or fathers who had sons to readily deem the CSA risk to their child to be low. Fig. 2 below presents a visual model about the general tendencies of parental risk perception and reactions related to the risk of CSA victimization. The model represents the most common patterns established during focus groups yet is not meant to be a definitive guide.

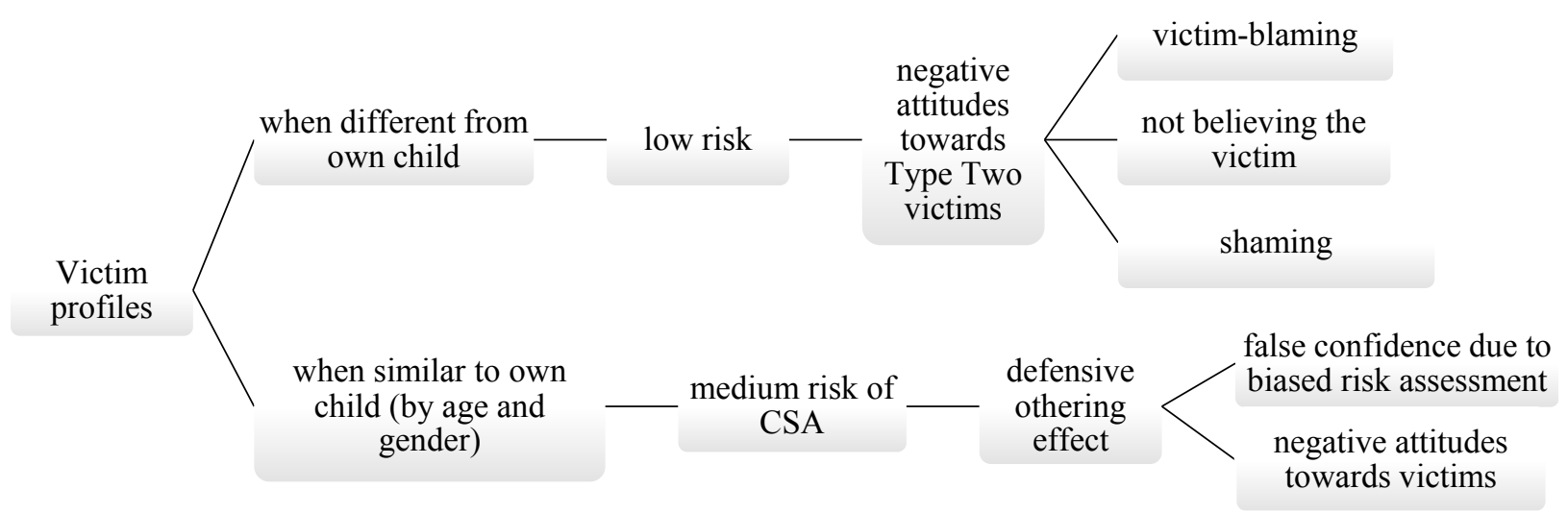

Fig. 2. A model of predominant parental risk perception and reaction patterns related to CSA victims

When parents or their children had similar factual characteristics with risk profiles, parents felt the need to construct "otherness" between themselves or their children and perceived victims; ergo, similarities seem to provoke an effect further referenced to as the defensive othering effect. The defensive othering effect represents a phenomenon where perceived similarities with the stigmatized group trigger a protective behavior of verbally distancing (othering) self (or someone else) from others. The concept of defensive othering itself has been 
mostly used to illustrate a coping mechanism used by disadvantaged groups who seek to distance themselves from people similar to them [37]. However, Fabbre and colleagues [38] proposed expanding the concept by theorizing that the notion of defending one's status due to perceived threat also applies to dominant groups. I believe such expansion is pertinent as such defensive patterns were recurring during all discussions.

The defensive othering effect was conspicuously reinforced in situations when similarities occurred between children and victim profiles. For parents of girls between the ages of 10 to 16 , the factual similarities were enough to provoke this effect. With defensive othering effect, parents went beyond constructing otherness based on stereotypical beliefs about victims and perpetrators, as they also used their children's behavior in general to support their beliefs about CSA risk to their child(ren). These general elements were related to their children's accomplishments, academic performance, and other such criteria. As there is no compelling evidence stating that good academic performance or other such achievements protect from sexual abuse, believing that merely being different from CSA victims exempts from abuse is a cognitive bias, a form of defensive attributions that aims to psychologically minimize the threat [33]. Strömpl [39] found the same effect with young people trying to juxtapose themselves to victims of online sexual abuse by presenting themselves as smarter or more reasonable.

Perpetrator related risk assessment is strongly connected to "strangers" or people "different" from themselves (or their children), likewise, the more similar the profile, the less of a general risk it was deemed to be $[11,40]$. For instance, the pervert was often described as ethnically different and considering Estonia is not a very diverse country and is still somewhat xenophobic, it is no surprise the "foreign pervert" was deemed as the most violent and dangerous [41]. In contrast, the exhibitionist, who was described as an old drunk man, yet with the same ethnic and cultural background, thus more familiar to parents, was not deemed much of a threat at all. The etiology of deviant sexual behavior was conceptualized differently across profiles, one as "being sick" yet not much of a threat, the other as predatory by nature. Fig. 3 presents a model of predominant parental risk perception and reaction patterns related to perpetrators of CSA.

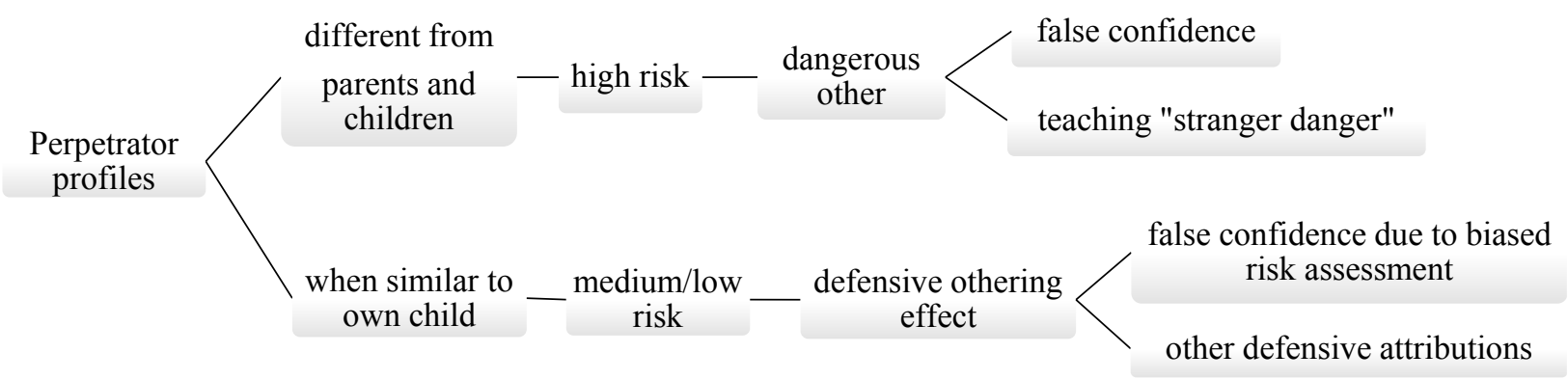

Fig. 3. A model of predominant parental risk perception and reaction patterns related to perpetrators of CSA

In case of tangible differences between either perpetrators and parents or their children, the risk was more firmly determined high. A similar notion was found in a study of young people's perceptions of so-called "online perverts" in Estonia, where young people also tend to conceptualize online abusers as "other" [41]. Fathers were more likely to see similarities between their teenage sons and the "spoiled rich kid" risk profile, and again, the similarities appeared to trigger defensive othering effect. This is driven by potential similarities inherent in 
that profile: other profiles differed immensely from their children in age, ethnicity, and other relevant characteristics. In such cases, other defensive attributions were triggered; these were about justifying perpetrators' actions or, in general, normalizing sexual violence. When I applied this finding of similar versus familiar to parental victim-blaming attitudes, it became evident that parents were more likely to justify perpetrators thought to be like their child and blame more such perpetrators who were notably different from themselves or their children. These findings give ancillary support for defensive attributions theory [33].

In accordance with previous studies, parents of girls consider the threat to be more real and hence provide their daughters with more information related to the prevention of CSA [3, 42]. The apparent gender stereotypes from fathers' perspective neglect entirely the possibility that their sons could be victims of sexual abuse. Negating the possibility of sexual victimization of boys reflects widespread heteronormative misconceptions in society. These views may act as barriers for boys to disclose abuse [21]. In general, the data from this study support previous research claiming parents consider the risk of CSA to their children to be low $[2-4,6,8]$.

It appeared that risk perception and resulting judgments dictate parents' behavior; most parents judge the risk to be low and, due to that, do not see the necessity for specific prevention activities [9, 10]. Here also, the most common CSA related discussion theme was still stranger danger $[2,3,7,10,13,14]$. Unfortunately, by relying on "stranger danger" to teach children about CSA (i. e., online perverts and pedophiles), parents tend to exclude important discussions about risks from peers, partners, and other known people. This may explain why most children only consider strangers as potential perpetrators. A 2010 study showed that children have difficulty recognizing the inappropriateness of sexual requests by trusted people [43]. These trusted people could be, for example, friends, family members, siblings, or relatives - i. e., the preeminent perpetrators [44]. However, if children are not taught about body safety in relation to real threats, they will have more difficulty recognizing abuse since physical force and violence are often not used to gain victims' compliance [45]. Also, following previous studies [2, 5], parents emphasize being a good parent, holding good parent-child relations, and providing a safe and stable environment for their children as main approaches to protect their children from the risk of CSA. Though previous studies have identified certain parenting practices, e. g., low involvement in child's life or neglect [46] and other parent-related factors, e. g., substance abuse, parental absence, and physical abuse [47] can statistically increase the risk of CSA, these factors are not absolute prerequisites to CSA and the lack of those does not provide immunity. The tremendous gap between parental beliefs and what academic literature suggests about CSA and CSA prevention is an important issue future CSA prevention efforts need to address.

Limitations and future research. One of the constraints of this study is the homogeneous sample. All parents lived either in urban or suburban areas; and were of similar socio-economic background. Addedly, although fathers' perspectives were, more than two-thirds of the participants were mothers; thus, this study can provide only limited insight into fathers' accounts. As some gender differences between mothers' and fathers' attitudes were observed, an equal representation of both genders may help to better capture such differences. The cultural context also impacts the findings. Estonia is not ethnically or racially diverse, and as intolerance persists, the conceptualization of threat is discernibly epitomized in such aspects. Further research with representative samples and perhaps in different cultural contexts could help to overcome these 
limitations. The significance and other implications of cognitive biases on risk assessment, attitudes towards victims and perpetrators, CSA prevention approaches, and other relevant issues should be a subject for further inquiry.

Conclusion. The findings suggest cognitive biases and psychological protection mechanisms may be a considerable influence on CSA risk assessment and the following approaches to protecting children. An important benefit of this study is the novel approach to conceptualizing why parents are so reluctant to discuss CSA. Further, the discussion reinforces the need to take cognizance of parental perception not necessarily being veracious. Educational programs should acknowledge the implications of subconscious protection mechanisms have on parental risk perception. It is also important to consider the wider impact of attitudes towards victims. Profiles parents created are social constructions of perceived victims and perpetrators of child sexual abuse. The unfortunate perseverance of these stereotypes further reproduces inequality, stigmatizes victimhood, and punishes the utmost vulnerable ones in society.

\section{REFERENCES}

1. Wurtele, S.K., (2009), "Preventing sexual abuse of children in the twenty-first century: Preparing for challenges and opportunities", Journal of Child Sexual Abuse, vol. 18 (1), pp. 1-18. DOI: http://dx.doi.org/10.1080/10538710802584650.

2. Rudolph, J. and Zimmer-Gembeck, M.J. (2018), "Parents as protectors: A qualitative study of parents' views on child sexual abuse prevention", Child Abuse \& Neglect, vol. 85, pp. 28-38. DOI: https://doi.org/10.1016/j.chiabu.2018.08.016.

3. Chen, J.Q. and Chen, D.G. (2005), "Awareness of child sexual abuse prevention education among parents of Grade 3 elementary school pupils in Fuxin City, China", Health education research, vol. 20, no. 5, pp. 540-547. DOI: https://doi.org/10.1093/her/cyh012.

4. Collins, M.E. (1996), "Parents' perceptions of the risk of child sexual abuse and their protective behaviors: Findings from a qualitative study", Child Maltreatment, vol. 1, no. 1, pp. 53-64. DOI: https://doi.org/10.1177/1077559596001001006.

5. Collins, M.E. (1995), Factors Influencing Parents' Perceptions and Behaviors Regarding the Threat of Sexual Abuse, available at: https://kb.osu.edu/handle/1811/36825 (accessed 11.01.2021).

6. Finkelhor, D. (1986), "The prevention of child sexual abuse: an overview of needs and problems", Sexual abuse of children I the 1980's: Ten essays and an annotated bibliography, in Schlesinger, B. (ed.), University of Toronto Press, Toronto, USA, pp. 16-29. DOI: 10.3138/9781487583392-003.

7. Walsh, K., Brandon, L. and Chirio, L. (2012), "Mother-child communication about sexual abuse prevention", Journal of Child Sexual Abuse, vol.21, no. 4, pp. 399-421. DOI: https://doi.org/10.1080/10538712.2012.675424.

8. Chen, J., Dunne, M.P. and Han, P. (2007), "Prevention of child sexual abuse in China: Knowledge, attitudes, and communication practices of parents of elementary school children", Child Abuse \& Neglect, vol. 31, no. 7, pp. 747-755. DOI: https://doi.org/10.1016/j.chiabu.2006.12.013.

9. Xie, Q.W., Qiao, D.P. and Wang, X.L. (2016), “Parent-involved prevention of child sexual abuse: a qualitative exploration of parents' perceptions and practices in Beijing", Journal of Child and Family Studies, vol. 25, pp. 999-1010. DOI: https://doi.org/10.1007/s10826-015-0277-5.

10. Burgess, E.S. and Wurtele, S.K. (1998), "Enhancing parent-child communication about sexual abuse: a pilot study", Child Abuse \& Neglect, vol.22, no. 11, pp. 1167-1175. DOI: https://doi.org/10.1016/S0145-2134(98)00094-5.

11. Deblinger, E., Thakkar-Kolar, R.R., Berry, E.J. and Schroeder, C.M. (2010), “Caregivers' efforts to educate their children about child sexual abuse: A replication study", Child Maltreatment, vol. 15, no. 1, pp. 91-100. DOI: https://doi.org/10.1177/1077559509337408. 
12. Briggs, F. (2006), "South Australian parents want child protection programs to be offered in schools and preschools", Early Child Development and Care, vol.34, no. 1, pp. 167-178. DOI: https://doi.org/10.1080/0300443880340112.

13. Rudolph, J., Zimmer-Gembeck, M.J., Shanley, D.C., Walsh, K. and Hawkins, R. (2018), "Parental discussion of child sexual abuse: Is it associated with the parenting practices of involvement, monitoring, and general communication?", Journal of child sexual abuse, vol. 27, no. 2, pp. 195-216. DOI: https://doi.org/10.1080/10538712.2018.1425946.

14. AlRammah, A.A., Alqahtani, S.M., Al-Saleh, S.S. et al. (2019), "Parent-child communication and preventive practices for child sexual abuse among the general population: A community-based study", Journal of Taibah University Medical Sciences, vol.14, no.4, pp. 363-369. DOI: https://doi.org/10.1016/j.jtumed.2019.06.005.

15. Babatsikos, G. (2011), "Australian parents, child sexuality, and boundary setting: informing preventative approaches to child sexual abuse", Child Abuse Review, vol. 19, no. 2, pp. 107-129. DOI: http://dx.doi.org/10.1002/car.1102.

16. Wurtele, S.K., Kvaternick, M. and Franklin, C.F. (1992), "Sexual abuse prevention for preschoolers: A survey of parents' behaviors, attitudes, and beliefs", Journal of Child Sexual Abuse, vol. 1, no. 1, pp. 113-128. DOI: https://doi.org/10.1300/J070v01n01_08.

17. Iglesias, E., Garmendia, M. and Casado del Río, M.A. (2015), "Children's perception of the parental mediation of the risks of the internet", Revista Latina de Comunicacion Social, vol. 70, pp. 4968. DOI: 10.4185/RLCS-2015-1034.

18. Bahali, K., Akçan, R., Tahiroglu, A.Y. and Avci, A. (2010), "Child sexual abuse: seven years in practice", Journal of forensic sciences, vol. 55, no. 3, pp. 633-636. DOI: https://doi.org/10.1111/j.15564029.2010.01357.x.

19. Vizard, E., Hickey, N., French, L. and McCrory, E. (2007), "Children and adolescents who present with sexually abusive behaviour: A UK descriptive study", The Journal of Forensic Psychiatry \& Psychology, vol. 18, no. 1, pp. 59-73. DOI: https://doi.org/10.1080/14789940601056745.

20. Sklenarova, H., Schulz, A., Schuhmann, P. et al. (2018), "Online sexual solicitation by adults and peers-Results from a population based German sample", Child Abuse \& Neglect, vol. 76, pp. 225236. DOI: https://doi.org/10.1016/j.chiabu.2017.11.005.

21. Alaggia, R., Collin-Vézina, D. and Lateef, R. (2019), "Facilitators and barriers to child sexual abuse (CSA) disclosures: A research update (2000-2016)", Trauma, Violence, \& Abuse, vol. 20, no. 2 , pp. 260-283. DOI: https://doi.org/10.1177/1524838017697312.

22. Hébert, M., Tourigny, M., Cyr, M. et al. (2009), "Prevalence of childhood sexual abuse and timing of disclosure in a representative sample of adults from Quebec", The Canadian Journal of Psychiatry, vol. 54, no. 9, pp. 631-636. DOI: https://doi.org/10.1177/070674370905400908.

23. Sukk, M., Soo, K., Kalmus, V. et al. (2019), EU Kids Online'i Eesti 2018. aasta uuringu esialgsed tulemused, University of Tartu, Tartu, Estonia. DOI: 10.13140/RG.2.2.32549.55526.

24. Elfreich, M.R., Stevenson, M.C., Sisson, C. et al. (2020), "Sexual abuse disclosure mediates the effect of an abuse prevention program on substantiation", Child maltreatment, vol. 25, no. 2, pp. 215223. DOI: https://doi.org/10.1177/1077559519874884.

25. Crotty, M. (1998), The Foundations of Social Research: Meaning and Perspective in the Research Process, 1st ed., SAGE, Melbourne, Australia.

26. Frith, H. (2000), "Focusing on sex: Using focus groups in sex research", Sexualities, vol. 3 , no. 3, pp. 275-297. DOI: https://doi.org/10.1177/136346000003003001.

27. Morgan, D.L. and Krueger, R.A. (1998), Analyzing and Reporting Focus Group Results, SAGE, Thousand Oaks, California. DOI: http://dx.doi.org/10.4135/9781483328157.

28. Kitzinger, J. (1994), "The methodology of focus groups: the importance of interaction between research participants", Sociology of health \& illness, vol. 16, no. 1, pp. 103-121. DOI: https://doi.org/10.1111/1467-9566.ep11347023.

29. Fairclough, N. (1989), Language and Power, Longman, London, UK. 
30. Colucci, E. (2007), "'“Focus groups can be fun": The use of activity-oriented questions in focus group discussions", Qualitative health research, vol.17, no.10, pp.1422-1433. DOI: https://doi.org/10.1177/1049732307308129.

31. Sherriff, N., Gugglberger, L., Hall, C. and Scholes, J. (2014), "'“From start to finish": Practical and ethical considerations in the use of focus groups to evaluate sexual health service interventions for young people", Qualitative Psychology, vol. 1, no. 2, pp. 92-106. DOI: https://doi.org/10.1037/qup0000014.

32. Braun, V. and Clarke, V. (2006), "Using thematic analysis in psychology", Qualitative research in psychology, vol. 3, no. 2, pp. 77-101. DOI: 10.1191/1478088706qp063oa.

33. Shaver, K.G. and Drown, D. (1986), "On causality, responsibility, and self-blame: A theoretical note", Journal of personality and social psychology, vol. 50, no. 4, pp.697-702. DOI: https://doi.org/10.1037/0022-3514.50.4.697.

34. Muehlenhard, C.L., Powch, I.G., Phelps, J.L. and Giusti, L.M. (1992), “Definitions of rape: Scientific and political implications", Journal of Social Issues, vol.48, no.1, pp.23-44. DOI: https://doi.org/10.1111/j.1540-4560.1992.tb01155.x.

35. Anderson, I. and Doherty, K. (2007), Accounting for rape: Psychology, feminism and discourse analysis in the study of sexual violence, Routledge, London, N.Y.

36. Ahven, A., Kruusmaa K.-C., Leps, A. et al. (2019), "Kuritegevus Eestis 2018", Justiitsministeerium, Kriminaalpoliitika uuringud 28, Tallin, Estonia available at: https://www.kriminaalpoliitika.ee/et/kuritegevus-eestis-2018 (accessed 16.01.2021).

37. Schwalbe, M., Holden, D., Schrock, D. et al. (2000), "Generic processes in the reproduction of inequality: An interactionist analysis", Social forces, vol.79, no. 2, pp.419-452. DOI: https://doi.org/10.1093/sf/79.2.419.

38. Fabbre, V.D., Gaveras, E., Shabsin, A.G. et al. (2019), “Confronting Stigma, Discrimination, and Social Exclusion", Toward a Livable Life: A 21st Century Agenda for Social Work, in Rank, M.R. (ed.), Oxford University Press, Oxford, UK, pp. 70-93.

39. Strömpl, J. (2015), "Online Risks: Adapting an Interactive Dialogical Narrative Method for Studying the Process of Meaning Making by Teenagers in the Focus Group Interview Context", "In Search of ...": New Methodological Approaches to Youth Research, Cambridge Scholars Publishing, Cambridge, UK, pp. 194-215.

40. Kristeva, J. (1991), Strangers to ourselves, Columbia University Press, N.Y., USA.

41. Murumaa-Mengel, M. (2015), "Drawing the Threat: A Study on Perceptions of the Online Pervert among Estonian High School Students", YOUNG, vol.23, no. 1, pp. 1-18. DOI: https://doi.org/10.1177/1103308814557395.

42. Jin, Y., Chen, J. and Yu, B. (2019), "Parental practice of child sexual abuse prevention education in China: Does it have an influence on child's outcome?", Children and Youth Services Review, vol. 96, pp. 64-69. DOI: https://doi.org/10.1016/j.childyouth.2018.11.029.

43. Kenny, M.C. and Wurtele, S.K. (2010), "Children's abilities to recognize a "good" person as a potential perpetrator of childhood sexual abuse", Child Abuse \& Neglect, vol. 34, no. 7, pp. 490-495. DOI: https://doi.org/10.1016/j.chiabu.2009.11.007.

44. Finkelhor, D. (2008), Childhood Victimization: Violence, Crime, and Abuse in the Lives of Young People, Oxford University Press, Oxford, UK. DOI 10.1093/acprof:oso/9780195342857.001.0001.

45. Leclerc, B., Wortley, R. and Smallbone, S. (2011), "Victim resistance in child sexual abuse: A look into the efficacy of self-protection strategies based on the offender's experience", Journal of interpersonal violence, vol. 26, no. 9, pp. 1868-1883. DOI: https://doi.org/10.1177/0886260510372941.

46. Testa, M., Hoffman, J.H. and Livingston, J.A. (2011) "Intergenerational transmission of sexual victimization vulnerability as mediated via parenting", Child Abuse \& Neglect, vol. 35, no. 5, pp. 363371. DOI: https://doi.org/10.1016/j.chiabu.2011.01.010.

47. Laaksonen, T., Sariola, H., Johansson, A. et al. (2011), "Changes in the prevalence of child sexual abuse, its risk factors, and their associations as a function of age cohort in a Finnish 
population sample", Child Abuse \& Neglect, vol. 35, no. 7, pp. 480-490. DOI: https://doi.org/10.1016/j.chiabu.2011.03.004.

\section{Information about the author.}

Simone Eelmaa - Master (International law and human rights) (2018), Doctoral student (Sociology) at the Institute of Social Studies, University of Tartu, 36 Lossi, Tartu 51010, Estonia. The author of 4 scientific publications. Area of expertise: criminal law, criminology, discourse analysis, and studying vulnerable populations. E-mail: simone.eelmaa@ut.ee

\section{СПИСОК ЛИТЕРАТУРЫ}

1. Wurtele S. K. Preventing sexual abuse of children in the twenty-first century: Preparing for challenges and opportunities // J. of Child Sexual Abuse. 2009. Vol. 18(1). P. 1-18. DOI: http://dx.doi.org/10.1080/10538710802584650.

2. Rudolph J., Zimmer-Gembeck M. J. Parents as protectors: A qualitative study of parents' views on child sexual abuse prevention // Child Abuse \& Neglect. 2018. Vol. 85. P. 28-38. DOI: https://doi.org/10.1016/j.chiabu.2018.08.016.

3. Chen J. Q., Chen D. G. Awareness of child sexual abuse prevention education among parents of Grade 3 elementary school pupils in Fuxin City, China // Health education research. 2005. Vol. 20, № 5. P. 540-547. DOI: https://doi.org/10.1093/her/cyh012.

4. Collins M. E. Parents' perceptions of the risk of child sexual abuse and their protective behaviors: Findings from a qualitative study // Child Maltreatment. 1996. Vol. 1, № 1. P. 53-64. DOI: https://doi.org/10.1177/1077559596001001006.

5. Collins M. E. Factors Influencing Parents' Perceptions and Behaviors Regarding the Threat of Sexual Abuse. 1995. URL: https://kb.osu.edu/handle/1811/36825 (дата обращения: 11.01.2021).

6 . Finkelhor D. The prevention of child sexual abuse: an overview of needs and problems // Sexual abuse of children I the 1980's: Ten essays and an annotated bibliography / in B. Schlesinger (ed.). Toronto: University of Toronto Press, 1986. P. 16-29. DOI: 10.3138/9781487583392-003.

7. Walsh K., Brandon L., Chirio L. Mother-child communication about sexual abuse prevention // J. of Child Sexual Abuse. 2012. Vol. 21, № 4. P. 399-421. DOI: https://doi.org/10.1080/ 10538712.2012 .675424$.

8. Chen J., Dunne M. P., Han P. Prevention of child sexual abuse in China: Knowledge, attitudes, and communication practices of parents of elementary school children // Child Abuse \& Neglect. 2007. Vol. 31, № 7. P. 747-755. DOI: https://doi.org/10.1016/j.chiabu.2006.12.013.

9. Xie Q. W., Qiao D. P., Wang X. L. Parent-involved prevention of child sexual abuse: a qualitative exploration of parents' perceptions and practices in Beijing // J. of Child and Family Studies. 2016. Vol. 25. P. 999-1010. DOI: https://doi.org/10.1007/s10826-015-0277-5.

10. Burgess E. S., Wurtele S. K. Enhancing parent-child communication about sexual abuse: a pilot study // Child Abuse \& Neglect. 1998. Vol. 22, №11. P. 1167-1175. DOI: https://doi.org/10.1016/S0145-2134(98)00094-5.

11. Caregivers' efforts to educate their children about child sexual abuse: A replication study / E. Deblinger, R. R. Thakkar-Kolar, E. J. Berry, C. M. Schroeder // Child Maltreatment. 2010. Vol. 15, № 1. P. 91-100. DOI: https://doi.org/10.1177/1077559509337408.

12. Briggs F. South Australian parents want child protection programs to be offered in schools and preschools // Early Child Development and Care. 2006. Vol. 34, № 1. P. 167-178. DOI: https://doi.org/10.1080/0300443880340112.

13. Parental discussion of child sexual abuse: Is it associated with the parenting practices of involvement, monitoring, and general communication? / J. Rudolph, M. J. Zimmer-Gembeck, D. C. Shanley, K. Walsh, R. Hawkins // J. of child sexual abuse. 2018. Vol. 27, № 2. P. 195-216. DOI: https://doi.org/10.1080/10538712.2018.1425946. 
14. Parent-child communication and preventive practices for child sexual abuse among the general population: A community-based study / A. A. AlRammah, S. M. Alqahtani, S. S. Al-Saleh et al. // J. of Taibah University Medical Sciences. 2019. Vol. 14, № 4. P. 363-369. DOI: https://doi.org/10.1016/j.jtumed.2019.06.005.

15. Babatsikos G. Australian parents, child sexuality, and boundary setting: informing preventative approaches to child sexual abuse // Child Abuse Rev. 2011. Vol. 19, № 2. P. 107-129. DOI: http://dx.doi.org/10.1002/car.1102.

16. Wurtele S. K., Kvaternick M., Franklin C.F. Sexual abuse prevention for preschoolers: A survey of parents' behaviors, attitudes, and beliefs // J. of Child Sexual Abuse. 1992. Vol. 1, № 1. P. 113-128. DOI: https://doi.org/10.1300/J070v01n01_08.

17. Iglesias E., Garmendia M., Casado del Río M. A. Children's perception of the parental mediation of the risks of the internet // Revista Latina de Comunicacion Social. 2015. Vol. 70. P. 4968. DOI: 10.4185/RLCS-2015-1034.

18. Child sexual abuse: seven years in practice / K. Bahali, R. Akçan, A. Y. Tahiroglu, A. Avci // J. of forensic sciences. 2010. Vol. 55, № 3. P. 633-636. DOI: https://doi.org/10.1111/j.15564029.2010.01357.x.

19. Children and adolescents who present with sexually abusive behaviour: A UK descriptive study / E. Vizard, N. Hickey, L. French, E. McCrory // The J. of Forensic Psychiatry \& Psychology. 2007. Vol. 18, № 1. P. 59-73. DOI: https://doi.org/10.1080/14789940601056745.

20. Online sexual solicitation by adults and peers-Results from a population based German sample / H. Sklenarova, A. Schulz, P. Schuhmann et al. // Child Abuse \& Neglect. 2018. Vol. 76. P. 225236. DOI: https://doi.org/10.1016/j.chiabu.2017.11.005.

21. Alaggia R., Collin-Vézina D., Lateef R. Facilitators and barriers to child sexual abuse (CSA) disclosures: A research update (2000-2016) // Trauma, Violence, \& Abuse. 2019. Vol. 20, № 2. P. 260283. DOI: https://doi.org/10.1177/1524838017697312.

22. Prevalence of childhood sexual abuse and timing of disclosure in a representative sample of adults from Quebec / M. Hébert, M Tourigny, M. Cyr et al. // The Canadian J. of Psychiatry. 2009. Vol. 54, № 9. P. 631-636. DOI: https://doi.org/10.1177/070674370905400908.

23. EU Kids Online'i Eesti 2018. aasta uuringu esialgsed tulemused / M. Suk, K. Soo, V. Kalmus and et al. Tartu: University of Tartu, 2019. DOI: 10.13140/RG.2.2.32549.55526.

24. Sexual abuse disclosure mediates the effect of an abuse prevention program on substantiation / M. R. Elfreich, M. C. Stevenson, C. Sisson and et al. // Child maltreatment. 2020. Vol. 25, № 2. P. 215-223. DOI: https://doi.org/10.1177/1077559519874884.

25. Crotty M. The Foundations of Social Research: Meaning and Perspective in the Research Process. 1st ed. Melbourne: SAGE, 1998.

26. Frith H. Focusing on sex: Using focus groups in sex research // Sexualities. 2000. Vol. 3, № 3. P. 275-297. DOI: https://doi.org/10.1177/136346000003003001.

27. Morgan D. L., Krueger R. A. Analyzing and Reporting Focus Group Results. Thousand Oaks: SAGE, 1998. DOI: http://dx.doi.org/10.4135/9781483328157.

28. Kitzinger J. The methodology of focus groups: the importance of interaction between research participants // Sociology of health \& illness. 1994. Vol. 16, № 1. P. 103-121. DOI: https://doi.org/10.1111/1467-9566.ep11347023.

29. Fairclough N. Language and Power. London: Longman, 1989.

30. Colucci E. "Focus groups can be fun": The use of activity-oriented questions in focus group discussions // Qualitative health research. 2007. Vol.17, № 10. P. 1422-1433. DOI: https://doi.org/10.1177/1049732307308129.

31. "From start to finish": Practical and ethical considerations in the use of focus groups to evaluate sexual health service interventions for young people / N. Sherriff, L. Gugglberger, C. Hall, J. Scholes // Qualitative Psychology. 2014. Vol. 1, № 2. P. 92-106. DOI: https://doi.org/10.1037/qup0000014.

32. Braun V., Clarke V. Using thematic analysis in psychology // Qualitative research in psychology. 2006. Vol. 3, № 2. P. 77-101. DOI: 10.1191/1478088706qp063oa. 
33. Shaver K. G., Drown D. On causality, responsibility, and self-blame: A theoretical note // J. of personality and social psychology. 1986. Vol. 50, № 4. P. 697-702. DOI: https://doi.org/10.1037/00223514.50.4.697.

34. Definitions of rape: Scientific and political implications / C. L. Muehlenhard, I. G. Powch, J. L. Phelps, L. M. Giusti // J. of Social Issues. 1992. Vol.48, № 1. P. 23-44. DOI: https://doi.org/10.1111/j.1540-4560.1992.tb01155.x.

35. Anderson I., Doherty K. Accounting for rape: Psychology, feminism and discourse analysis in the study of sexual violence. London, N. Y.: Routledge, 2007.

36. Kuritegevus Eestis 2018 / A. Ahven, K.-C. Kruusmaa, A. Leps et al. // Justiitsministeerium, Kriminaalpoliitika uuringud 28. Tallin, 2019. URL: https://www.kriminaalpoliitika.ee/et/kuritegevuseestis-2018 (дата обращения: 16.01.2021).

37. Generic processes in the reproduction of inequality: An interactionist analysis / M. Schwalbe, D. Holden, D. Schrock et al. // Social forces. 2000. Vol. 79, № 2. P. 419-452. DOI: https://doi.org/10.1093/sf/79.2.419.

38. Confronting Stigma, Discrimination, and Social Exclusion / V. D. Fabbre, E. Gaveras, A. G. Shabsin et al. // Toward a Livable Life: A 21st Century Agenda for Social Work / in M. R. Rank (ed.). Oxford: Oxford University Press, 2019. P. 70-93.

39. Strömpl J. Online Risks: Adapting an Interactive Dialogical Narrative Method for Studying the Process of Meaning Making by Teenagers in the Focus Group Interview Context // "In Search of ...": New Methodological Approaches to Youth Research. Cambridge: Cambridge Scholars Publishing, 2015. P. 194-215.

40. Kristeva J. Strangers to ourselves. N. Y.: Columbia University Press, 1991.

41. Murumaa-Mengel M. Drawing the Threat: A Study on Perceptions of the Online Pervert among Estonian High School Students // YOUNG. Vol. 23, № 1. P. 1-18. DOI: https://doi.org/10.1177/1103308814557395.

42. Jin Y., Chen J., Yu B. Parental practice of child sexual abuse prevention education in China: Does it have an influence on child's outcome? // Children and Youth Services Review. 2019. Vol. 96. P. 64-69. DOI: https://doi.org/10.1016/j.childyouth.2018.11.029.

43. Kenny M. C., Wurtele S. K. Children's abilities to recognize a "good" person as a potential perpetrator of childhood sexual abuse // Child Abuse \& Neglect. 2010. Vol. 34, № 7. P. 490-495. DOI: https://doi.org/10.1016/j.chiabu.2009.11.007.

44. Finkelhor D. Childhood Victimization: Violence, Crime, and Abuse in the Lives of Young People. Oxford: Oxford University Press, 2008. DOI 10.1093/acprof:oso/9780195342857.001.0001.

45. Leclerc B., Wortley R., Smallbone S. Victim resistance in child sexual abuse: A look into the efficacy of self-protection strategies based on the offender's experience // J. of interpersonal violence. 2011. Vol. 26, № 9. P. 1868-1883. DOI: https://doi.org/10.1177/0886260510372941.

46. Testa M., Hoffman J. H., Livingston J.A. Intergenerational transmission of sexual victimization vulnerability as mediated via parenting // Child Abuse \& Neglect. 2011. Vol. 35, № 5. P. 363-371. DOI: https://doi.org/10.1016/j.chiabu.2011.01.010.

47. Changes in the prevalence of child sexual abuse, its risk factors, and their associations as a function of age cohort in a Finnish population sample / T. Laaksonen, H. Sariola, A. Johansson et al. // Child Abuse \& Neglect. 2011. Vol. 35, № 7. P. 480-490. DOI: https://doi.org/10.1016/j.chiabu.2011.03.004.

\section{Информация об авторе.}

Симоне Ээльма - магистр в области международного права и защиты прав человека (2018), докторант (социология) Института социальных наук Тартуского университета, ул. Лосси, д. 36, 51010, Эстония. Автор 4 научных публикаций. Сфера научных интересов: уголовное право, криминология, анализ дискурса и исследование уязвимых групп населения. E-mail: simone.eelmaa@ut.ee 